\title{
Cytogenetic studies in gomphocerine grasshoppers. I. Comparative analysis of chromosome $\mathrm{C}$-banding pattern
}

\author{
J. Cabrero and J. P. M. Camacho
}

Departamento de Genética, Facultad de Ciencias, Universidad de Granada, 18071 Granada, Spain.

Chromosome $\boldsymbol{C}$-banding pattern have been studied in $\mathbf{2 0}$ species of gomphocerine grasshoppers. Paracentromeric $\boldsymbol{C}$ bands were present in the chromosomes of all species analysed, which favours the equilocal model of heterochromatin distribution. Interstitial or distal $\boldsymbol{C}$-bands, on the other hand, appeared, at most, in two different chromosome pairs within the same chromosome complement, which is not expected on the equilocal model. Interspecific comparisons of $C$-banding patterns reveal the existence of differences between species of either the same or of different genera, which emphasises the dynamic nature of heterochromatin. The $X$ chromosome shows more similarities for $C$-banding between the species of the genera Stenobothrus, Euchorthippus, and Omocestus than between these species and those of Chorthippus, which seem to indicate the existence of a close relationship between these three genera.

\section{INTRODUCTION}

Acridid grasshoppers are very uniform in chromosome form and number (John and Hewitt, 1966). For this reason this family has long been regarded as chromosomally conservative since the majority have $2 n=22+\mathrm{XO} \delta / \mathrm{XX}$ \% telo-subtelocentric chromosomes. The Gomphocerinae is the most distinctive subfamily within the Acrididae since about half of the species analysed to date have $2 n=16+\mathrm{XO} \delta / \mathrm{XX}$ \% with three long metacentric chromosome pairs which are presumed to have arisen by centric fusions. Despite this apparent karyotypic conservatism, the Acrididae show extensive intraspecific variation for supernumerary chromosome segments (John and King, 1977; 1982; 1983; Hewitt, 1979; Camacho et al., 1984), as well as interspecific variation for $C$-banding (King and John, 1980; Santos et al., 1983) and nuclear DNA content (John and Hewitt, 1966; Kiknadze and Vysotskaya, 1969; Rees et al., 1978; Gosálvez et al., 1980).

In this paper we analyse $C$-banding pattern in 20 species of gomphocerine grasshoppers in order to determine the interspecific differences which exist between them.

\section{MATERIALS AND METHODS}

All the individuals analysed in this report were caught in the South of the Iberian Peninsula, and belong to the subfamily Gomphocerinae (Orthoptera, Acrididae). They include representatives of 20 species: specifically Truxalis nasuta (L.), Dociostaurus genei (Ocsk.), Ramburiella hispanica (Ramb.), Euchorthippus chopardi Desc., E. pulvinatus (F.-W.), Stenobothrus festivus Bol., S. grammicus (Caz.), Omocestus bolivari Chop., $O$. panteli (Bol.), O. raymondi (Yers.), O. llorenteae Pasc., Stauroderus scalaris (F.-W.), Chorthippus parallelus (Zett.), Ch. dorsatus (Zett.), Ch. jucundus (Fisch.), Ch. apicalis (H.-S.), Ch. nevadensis Pasc., Ch. binotatus (Charp.), Ch. vagans (Eversm.) and Ch. brunneus (Thunb.). In all a total of 771 male and 334 female adults were analysed together with 697 embryos.

Adult individuals were analysed cytologically by the methods described in Camacho and Cabrero (1982). The embryos were studied cytologically following the technique described by Webb et al. (1978), and C-banding was carried out as described in Camacho et al. (1984).

In all species analysed the autosomes have been classified into three size groups: $L$ (long), $M$ (medium) and $S$ (short).

\section{RESULTS}

In the majority of the 20 species analysed there were variations in the $C$-banding pattern involving 
the presence of supernumerary chromosome segments. These variations will be reported separately, and here we will consider the standard $C$-banding pattern found in a majority of individuals within the species analysed.

$C$-heterochromatin content and distribution in the 20 species are shown in figs. 1-20 and table 1 . $C$-bands may show three different locations: paracentromeric, interstitial and distal. Striking interspecific differences exist for $C$-banding pattern in respect of the presence or absence of interstitial and distal $C$-bands but more especially for the size of the paracentromeric bands.

\section{Paracentromeric C-bands}

The chromosomes of all species analysed, like those studied by King and John (1980) and Santos et al. (1983), have $C$-bands in the vicinity of the centromeric regions. However, these paracentromeric $C$-bands may be small, representing strictly centromeric heterochromatin, or large, in which case they are composed of both centric and proximal bands. The smallest centromeric $C$-bands occur in Omocestus raymondi (fig. 10) and Chorthippus dorsatus (fig. 14). Large compound paracentromeric $C$-bands are clearly exemplified in Stauroderus scalaris (fig. 12), Chorthippus binotatus (fig. 18) and Ch. brunneus (fig. 20). In a majority of the species, however, paracentromeric $C$-bands are intermediate between these two size extremes, though they may vary even between different chromosomes of the same species. For example, in Ramburiella hispanica (fig. 3) while the four larger chromosome pairs have large paracentromeric $C$-bans the remainder have medium or small bands. In Omocestus panteli (fig. 9) paracentromeric $C$-bands are medium sized, with exception of that in the $S_{8}$ which is small. Chorthippus apicalis (fig. 16) provides an extreme example of the heterogeneous distribution of paracentromeric $C$-heterochromatin since it shows large $C$-bands in the $L_{1}, L_{2}, L_{3}, M_{6}$ and $S_{8}$ chromosomes, medium $C$-bands in the $M_{7}$ and small $C$-bands in the $X, M_{4}$ and $M_{5}$. Other species show paracentromeric $C$-bands of medium size in all chromosomes; this is so in Euchorthippus chopardi (fig. 4), E. pulvinatus (fig. 5), Stenobothrus festivus (fig. 6), S. grammicus (fig. 7), Omocestus bolivari (fig. 8), O. llorenteae (fig. 11), Chorthippus parallelus (fig. 13), Ch. jucundus (fig. 15), Ch. nevadensis (fig. 17) and Ch. vagans (fig. 19).

\section{Interstitial C-bands}

While interstitial bands are frequent in some species of Australian acridoids (King and John, 1980; John et al., 1985) they are invariably scarce in Spanish species (Santos et al., 1983). In the present study we have observed them in 11 species but even here they never occur in more than two chromosome pairs in any one species. A majority

Table $1 C$-banding pattern in 20 species of gomphocerine grasshoppers

\begin{tabular}{|c|c|c|c|c|c|c|c|}
\hline \multirow[b]{2}{*}{ Species } & \multirow[b]{2}{*}{$2 n \sigma^{\star}$} & \multirow[b]{2}{*}{ Fig. } & \multicolumn{3}{|c|}{ Paracentromeric $C$-bands } & \multirow{2}{*}{$\begin{array}{l}\text { Interstitial } \\
C \text {-bands }\end{array}$} & \multirow{2}{*}{$\begin{array}{l}\text { Distal } \\
C \text {-bands }\end{array}$} \\
\hline & & & Large & Medium & Small & & \\
\hline Dociostaurus genei & 23 & 1 & - & $L_{2}-M_{4}, M_{8}$ & $L_{1}, M_{5}-M_{7}, X, M_{9}-S_{11}$ & $L_{1}$ & - \\
\hline Truxalis nasuta & 23 & 2 & - & $M_{9}, S_{10}$ & $L_{1}-M_{8}, S_{11}, X$ & $M_{9}$ & $M_{9}$ \\
\hline Ramburiella hispanica & 23 & 3 & $L_{1} M_{4}$ & $M_{5}-S_{11}, X$ & - & - & - \\
\hline Euchorthippus chopardi & 17 & 4 & - & All & - & $X$ & $L_{3}$ \\
\hline Euchorthippus pulvinatus & 17 & 5 & - & All & - & $M_{6}$ & - \\
\hline Stenobothrus festivus & 17 & 6 & - & All & - & - & $M_{6}$ \\
\hline Stenobothrus grammicus & 17 & 7 & - & All & - & - & - \\
\hline Omocestus bolivari & 17 & 8 & - & All & - & - & $X$ \\
\hline Omocestus panteli & 17 & 9 & - & All except $S_{8}$ & $S_{8}$ & $L_{3}$ & - \\
\hline Omocestus raymondi & 17 & 10 & - & - & All & $X$ & $L_{2}, L_{3}$ \\
\hline Omocestus llorenteae & 17 & 11 & - & All & - & $X$ & - \\
\hline Stauroderus scalaris & 17 & 12 & All & - & - & - & - \\
\hline Chorthippus parallelus & 17 & 13 & - & All & - & - & $L_{3}$ \\
\hline Chorthippus dorsatus & 17 & 14 & - & - & All & - & - \\
\hline Chorthippus jucundus & 17 & 15 & - & All & - & $L_{2}, L_{3}$ & - \\
\hline Chorthippus apicalis & 17 & 16 & $L_{1}-L_{3}, M_{6}, S_{8}$ & $M_{7}$ & $M_{4}, M_{5}, X$ & - & $M_{4}$ \\
\hline Chorthippus nevadensis & 17 & 17 & - & All & - & $L_{2}$ & $M_{6}, M_{7}$ \\
\hline Chorthippus binotatus & 17 & 18 & All & - & - & - & - \\
\hline Chorthippus vagans & 17 & 19 & - & All & - & $L_{2}, L_{3}$ & $M_{4}$ \\
\hline Chorthippus brunneus & 17 & 20 & All & - & - & $L_{2}, L_{3}$ & $\boldsymbol{M}_{7}$ \\
\hline
\end{tabular}




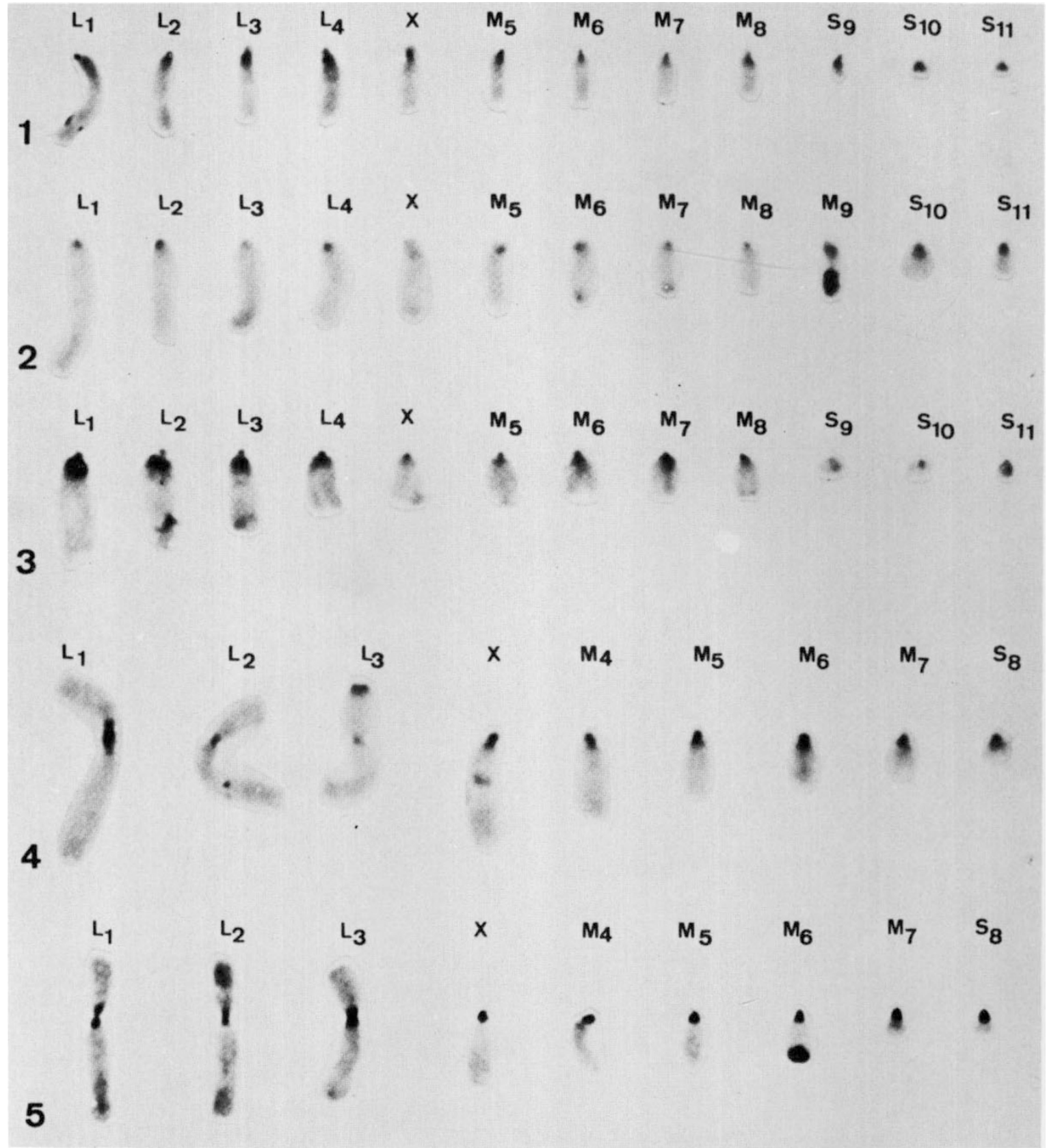

Figures 1-5 C-banding pattern in the haploid chromosome complements of gomphocerine grasshoppers. (1) Dociostaurus genei, (2) Truxalis nasuta, (3) Ramburiella hispanica, (4) Euchorthippus chopardi, (5) E. pulvinatus.

of interstitial $C$-bands are located in the long $(L)$ and the $X$ chromosomes. This includes the $X$ of Euchorthippus chopardi (fig. 4), Omocestus raymondi (fig. 10) and O. llorenteae (fig. 11), the $L_{2}$ of Chorthippus nevadensis (fig. 17), the $L_{3}$ of $O$. panteli (fig. 9) and the $L_{2}$ and the $L_{3}$ of $C h$. jucundus (fig. 15), Ch. vagans (fig. 19) and Ch. brunneus (fig. 20). The megameric $M_{9}$ chromosome of Truxalis nasuta (fig. 2) has an interstitial $C$-band and, finally, the megameric $M_{6}$ chromosome of Euchorthippus pulvinatus (fig. 5) possesses an apparently distal $C$-band which, in less condensed chromosomes, is clearly interstitial (see figs. 3 and 4 in Santos and Giráldez, 1982). 


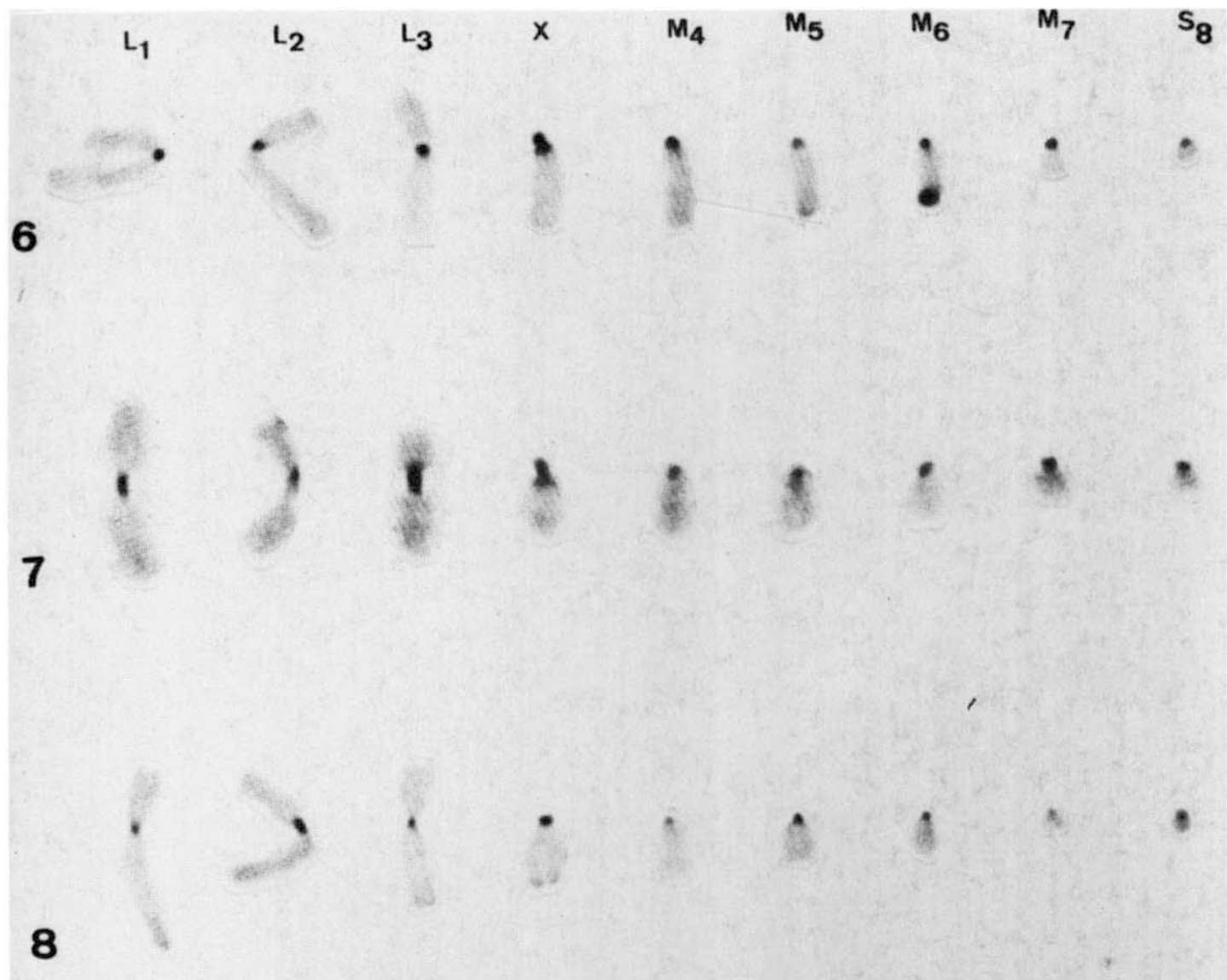

9
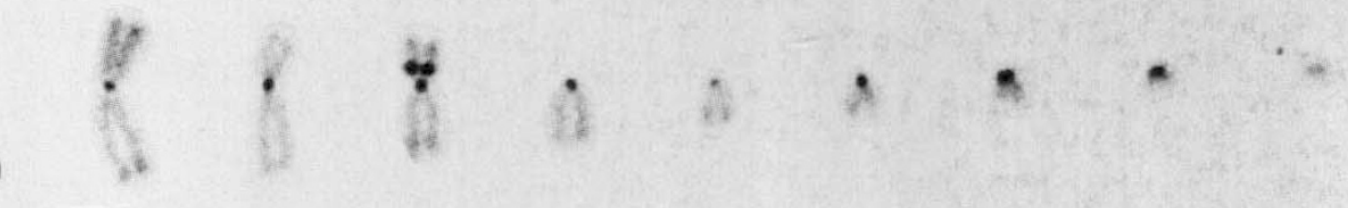

10
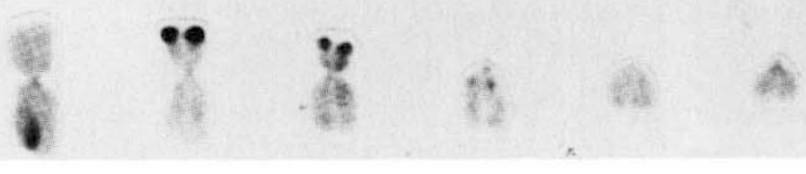

Figures 6-10 C-banding pattern in the haploid chromosome complements of gomphocerine grasshoppers. (6) Stenobothrus festivus, (7) S. grammicus, (8) Omocestus bolivari, (9) O. panteli, (10) O. raymondi. 


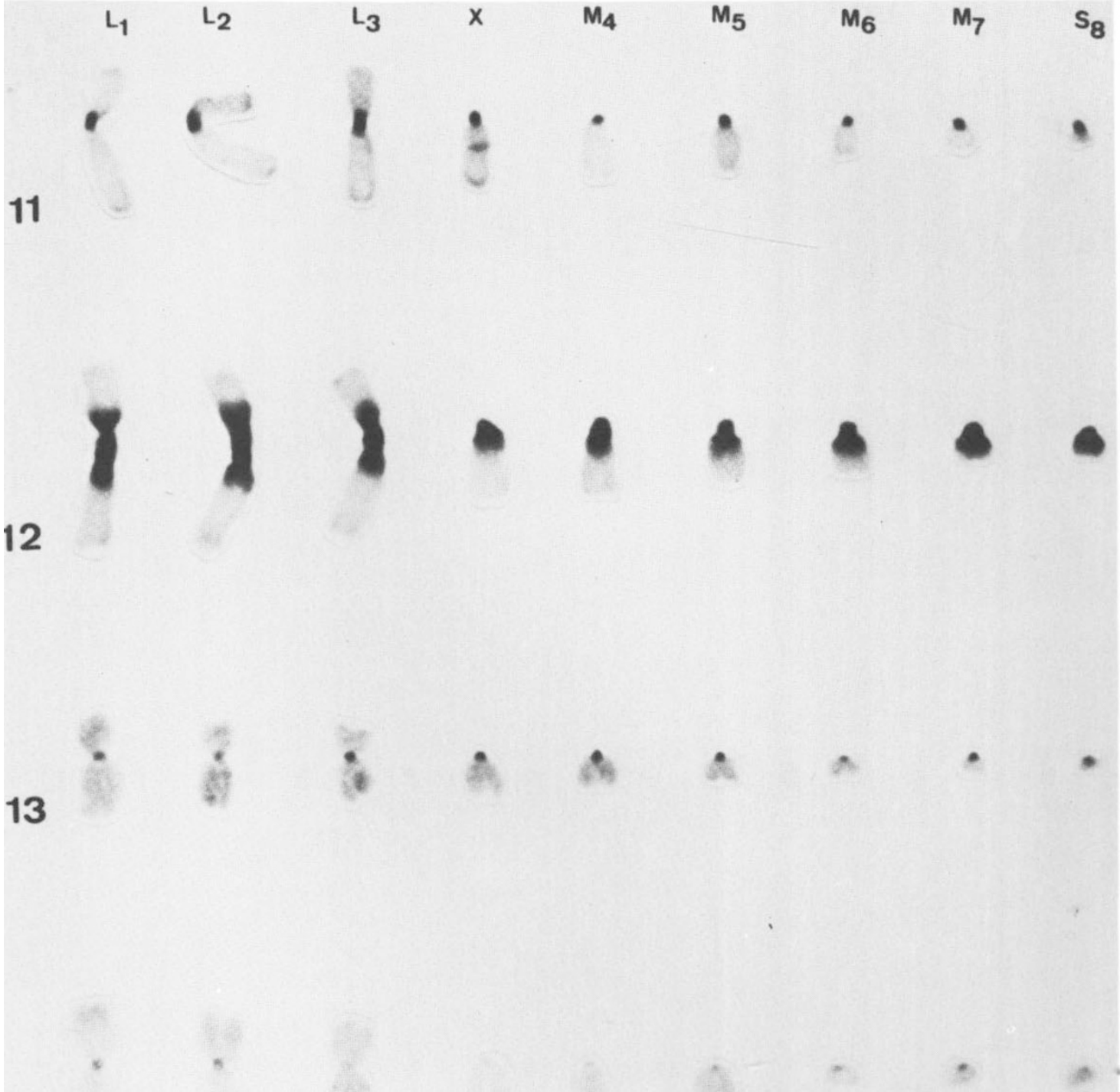

14

15

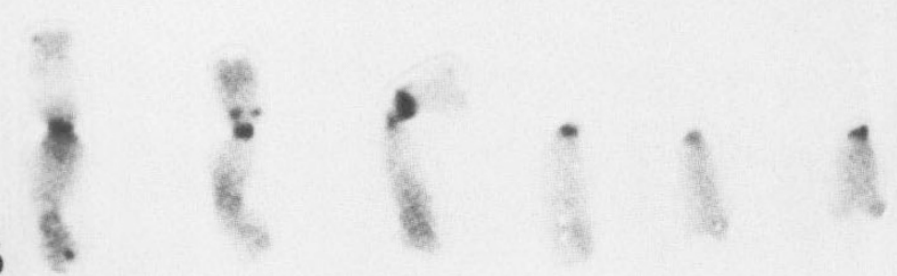

Figures 11-15 C-banding pattern in the haploid chromosome complements of gomphocerine grasshoppers. (11) Omocestus llorenteae, (12) Stauroderus scalaris, (13) Chorthippus parallelus, (14) Ch. dorsatus, (15) Ch. jucundus. 


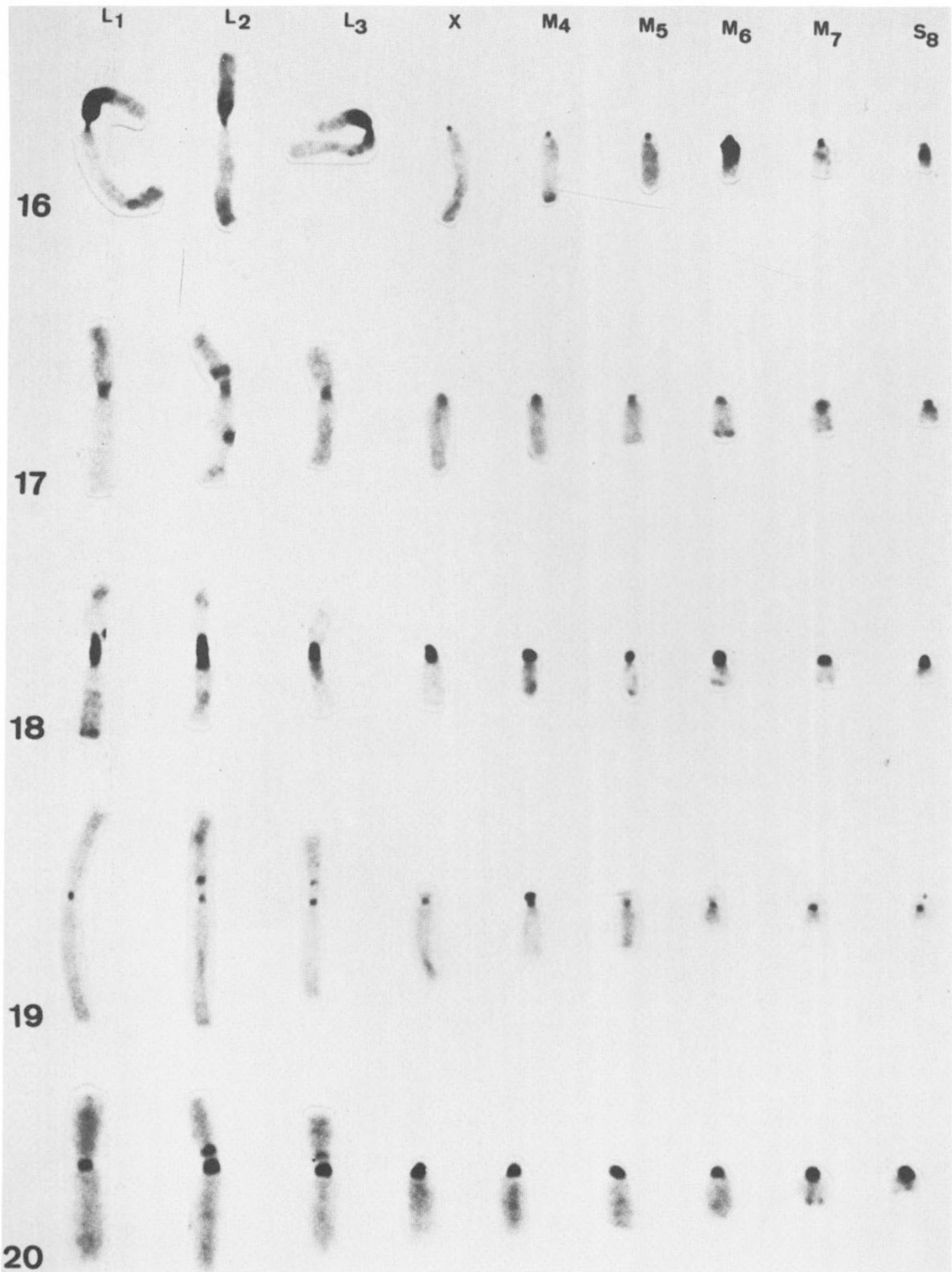

Figures 16-20 C-banding pattern in the haploid chromosome complements of gomphocerine grasshoppers. (16) Chorthippus apicalis, (17) Ch. nevadensis, (18) Ch. binotatus, (19) Ch. vagans, (20) Ch. brunneus. 


\section{Distal C-bands}

These are as infrequent as the interstistial $C$-bands and, like them, appear at most in two chromosome pairs within the same species. In the majority of cases the distal $C$-bands are small in size. This is so in the $M_{7}$ chromosomes of Chorthippus brunneus (fig. 20), the $M_{6}$ and $M_{7}$ of $C h$. nevadensis (fig. 17), the $M_{4}$ of $C h$. apicalis (fig. 16), and the $X$ of Omocestus bolivari (fig. 8). In other species, distal $C$-bands are medium or large, as is the case in the $L_{3}$ chromosome of Euchorthippus chopardi (fig. 4), the $L_{2}$ and $L_{3}$ of Omocestus raymondi (fig. 10), the $M_{6}$ of Stenobothrus festivus (fig. 6), the $M_{9}$ of Truxalis nasuta (fig. 2) and the $C$-band in the short arm of the $M_{4}$ chromosome of Chorthippus vagans (fig. 19).

\section{DISCUSSION}

The $C$-banding patterns of the 20 gomphocerine species analysed in this paper, like those of other acridoid grasshoppers (King and John, 1980; Santos et al., 1983), fit the equilocal model for heterochromatin distribution proposed by Heitz (1933; 1935). Thus the 'constitutive heterochromatin of non homologous chromosomes of a same diploid set tends to be located in similar sites". Without doubt, paracentromeric $C$-bands provide the strongest support for the equilocal model, given that their presence is constant in all chromosomes of all species, and that their size is usually uniform for a majority of the chromosomes within a given species. Exceptionally, as in Dociostaurus genei and Truxalis nasuta, paracentromeric $C$-bands are medium sized in some chromosomes but small in others, while in Ramburiella hispanica they may be large or medium, and in Chorthippus apicalis there are large, medium and small paracentromeric $C$-bands. Recent studies of acridoid $C$-heterochromatin by fluorochromes (John et al., 1985) have demonstrated that $C$-heterochromatic blocks which occupy similar positions on non homologous chromosomes in a species do not necessarily coincide either in size or in composition. This heterochromatin heterogeneity, shown by differential fluorescence, implies that equilocality as defined by position does not apply invariably to structure. Interspecific comparisons of $C$ banding patterns reveal differences between species of either the same or of different genera (Santos et al., 1983; this paper), which undoubtedly is also due to the dynamic nature of heterochromatin (Morescalchi, 1977). It is important to recognise that interspecific comparisons are limited by the fact that one cannot be sure that chromosomes of similar relative length are necessarily homologous in all genomes (King and John, 1980). The only possible exceptions are the $X$ and the megameric chromosomes, two elements which, presumably, each have a common origin within the Acrididae. However, in spite of the heteropycnosis of both chromosomes during male meiosis, their responses to $C$-banding are not especially distinctive. The only recognisable megameric chromosomes which show an unusual $C$ banding pattern are the $M_{9}$ chromosome of Truxalis nasuta (fig. 2) and the $M_{6}$ of Euchorthippus pulvinatus (fig. 5), Stenobothrus festivus (fig. 6), Chorthippus apicalis (fig. 16) and Ch. nevadensis (fig. 17). On the other hand, some $X$ chromosomes show a $C$-band located proximally as in Stenobothrus festivus (fig. 6) and S. grammicus (fig. 7), interstitially as in Euchorthippus chopardi (fig. 4), Omocestus raymondi (fig. 10) and O. llorenteae (fig. 11 ) or distally as in O. bolivari (fig. 8). While the megameric chromosomes of these species do not seem to have much in common, the $X$ chromosomes show more similarities between the species of the genera Stenobothrus, Euchorthippus and Omocestus than between these and the species of Chorthippus, which suggests a close relationship between these three genera. However, neither the similarities nor the differences between these genera are absolute, which implies that the evolutionary relationship of these taxa is too complex to be deduced from $C$-banding patterns. In other words, $C$-banding patterns may change so quickly that they do not provide sensible evolutionary markers. The pronounced tendency for $C$-heterochromatin to vary in grasshoppers has been evidenced by many reports (John and King, 1977; 1982; 1983; Hewitt, 1979; Santos et al., 1983; Camacho et al., 1984) but especially by those of Shaw et al. (1976).

A further fact that merits comment is the origin of the short arms of subtelocentric chromosomes in some species. While in Stauroderus scalaris (fig. 12), Chorthippus binotatus (fig. 18) and Ch. brunneus (fig. 20) they appear deeply stained following $C$-banding, in Ch. vagans (fig. 19), with the exception of the $M_{4}$ chromosome, the short arms of the $M, S$ and $X$ chromosomes do not $C$-band. Consequently, while darkly $C$-banded short arms would have arisen by amplification, those of $C h$. vagans have presumably arisen by pericentric inversion. These two types of chromosomal rearrangements have also been held to explain the origin of different kinds of short arms in the chromosomes of different species of Australian morabine grasshoppers (White, 1975). 
Acknowledgements We are grateful to Dr F. Pascual for the taxonomic identification of the material studied and professor B. John for the critical reading of the manuscript.

\section{REFERENCES}

CAMACHO, J. P. M. AND CABRERO, J. 1982. Supernumerary segments in five species of grasshoppers (Orthoptera: Acridoidea). Genetica, 59, 113-117.

CAMACHO, J. P. M., VISERAS, E., NAVAS, J. AND CABRERO, J. 1984. $C$-heterochromatin content of supernumerary chromosome segments of grasshoppers: detection of an euchromatic extra segment. Heredity, 53, 167-175.

GOSALVEZ, J., LOPEZ FER NANDEZ, C. AND ESPONDA, P. 1980. Variability of the DNA content in five orthopteran species. Caryologia, 33, 275-281.

HEITZ, E. 1933. Die somatısche Heteropyknode bei Drosophila melanogaster und ihre genetische Bedeutung. Z. Zellforsch, 20, 237-287.

HEITZ, E 1935. Die Herkunft der Chromozentren. Planta (Berl.), 18, 571-635.

HEWITT, G. M. 1979. Grasshoppers and crickets. Animal Cytogenetics. Vol. 3: Insecta 1 Orthoptera, Gebrüder Borntraeger, Berlin-Stuttgart.

JOHN, B. AND HEWITT, G. M. 1966. Karyotype stability and DNA variability in the Acrididae. Chromosoma, 20, 155172.

JOHN, B. AND KING, M. 1977. Heterochromatin variation in Cryptobothrus chrysophorus. II. Patterns of $C$-banding. Chromosoma, 65, 59-79.

JOHN, B. AND KING, M. 1982. Meiotic effects of supernumerary heterochromatin in Heteropternis obscurella. Chromosoma, $85,39-65$.

JOHN, B. AND KING, M. 1983. Population cytogenetics of Atractomorpha similis. I. C-band variation. Chromosoma, $88,57-68$.
JOHN, B., KING, M., SCHWEIZER, D. AND MENDELAK, M. 1985. Equilocality of heterochromatin distribution and heterochromatin heterogeneity in acridid grasshoppers. Chromosoma, 91, 185-200.

KIKNADZE, I. J. AND VYSOTSKAYA, L.V. 1969. Measurement of DNA mass per nucleus in the grasshopper species with different numbers of chromosomes. Tsitologia, 12, 11001107.

KING, M. AND JOHN, B. 1980. Regularities and restrictions governing $C$-band variation in Acridoid grasshoppers. Chromosoma, 76, 123-150.

MORESCALCHI, A. 1977. Phylogenetic aspects of karyological evidence. In: Major patterns of vertebrate evolution, $\mathrm{pp}$. 149-167. M. K. Hecht, P. C. Goody, and B. M. Hecht, eds. New York: Plenum Press Corporation.

REES, H., SHAW, D. D. AND WILKINSON, P. 1978. Nuclear DNA variation among acridid grasshoppers. Proc. R. Soc. Lond. B., 202, 517-525.

SANTOS, J. L., ARANA, P. AND GiRAldez, R. 1983. Chromosome $C$-banding patterns in Spanish Acridoidea. Genetica, $61,65-74$.

SANTOS, J. L. AND GIRALDEZ, R. 1982. C-heterochromatin polymorphism and variation in chiasma localization in Euchorthippus pulvinatus gallicus (Acrididae, Orthoptera). Chromosoma, 85, 507-518.

SHAW, D. D., WEBB, G. C. AND WILKINSON, P. 1976. Population cytogenetics of the genus Caledia (Orthoptera: Acrididae). II. Variation in the pattern of C-banding. Chromosoma, 56, 169-190.

WEBB, G. C., WHITE, M. J. D., CONTRERAS, N. AND CHENEY, J. 1978. Cytogenetics of the parthenogenetic grasshopper Warramaba (formerly Moraba) virgo and its bisexual relatives. IV. Chromosome banding studies. Chromosoma, 67, 309-339.

WHITE, M. J. D. 1975. Chromosomal repatterning-regularities and restrictions. Genetics, 79, 63-72. 